\title{
An International Perspective on Under-representation of Female Leaders in Kenya's Primary Schools
}

\author{
Bosire Monari Mwebi \\ Angeliki Lazaridou
}

\begin{abstract}
Studies of school administrators in North America, Europe, and Australia have shown consistently that women, although a majority in the teaching force, are under-represented in leadership positions. This study examine whether the factors associated with under-representation of women in school administration in Kenya are the same as they are in other countries. The female participants identified six barriers. These are, family obligations, cultural beliefs, unethical recruitment practices, lack of networking, low expectation of success, lack of role models and mentors. The participants further identified four areas for improvements. These are, educating the public, training and exemplars, and recruitment.

Résumé

Les recherches sur les administrateurs des écoles en Amérique du Nord, en Europe, et en Australie ont montré régulièrement que les femmes, qui pourtant font la majorité de l'effectif des enseignants, sont toujours sous-représentées dans les positions de dirigeants. Cette recherche a pour but d'examiner si les facteurs associés à cette sous représentation sont les mêmes que dans les autres pays. Les participantes à cette recherche ont identifié six obstacles. Ce sont: les obligations familiales, les croyances culturelles, les pratiques peu éthiques de recrutement, le manque de gestion de réseau, une espérance non élevée de succès, et le manque de modèles à émuler ou de mentors. Les participantes ont ensuite identifié quatre domaines où l'on pourrait effectuer les améliorations. Ce sont: l'éducation du public, la formation, des modèles, et le recrutement.
\end{abstract}

Studies of school administrators in North America, Europe, and Australia have shown consistently that women in the teaching force, although a majority, are under-represented in leadership positions (e.g., Young, 1990; 1994; Canadian Teachers' Federation, 1999; Ministry of Education (Greece), 1999; Smith, 1991). In many instances those studies also show that female representation in administrative positions at the primary school level has been increasing.

In Kenya the situation is similar. The first author of this paper - with 15 years of experience as teacher, Inspector of Schools, and Education Administrator of rural districts in Kenya - has seen that women are seriously under-represented in the administration of primary schools and that there has been no improvement in recent times. 
Since the Kenyan context is unique, it is legitimate to ask whether the factors associated with under-representation of women in school administration are the same in Kenya as they are in other countries. The available literature, however, provides few insights. One problem is that most studies of female underrepresentation in school administration have been conducted in North America, England, and Australia (e.g., Lyman, Ashby, and Tripses, 2005; Smith, 1991; Young, 1990 \& 1994; ). A second problem is that the relevant literature about Kenya's schools is limited to the post-secondary sector and scant (MwangiChemnjor, 1995). A third problem is that, until recently, the literature has been quantitative and lacking a constructivist perspective.

To address these problems, we concluded, we would have to get information about the experiences of female school administrators in Kenya by interviewing female teachers who aspired to become Head of a school, as well as those who had attained the principalship. We were of the view that stories about their experiences while striving for and attaining a headship could reveal important factors and dynamics that might be of international interest.

The purpose of this paper is to report on such a study, one designed to investigate why there are fewer females than males in primary school headships in Kenya, and to determine how this situation might be improved. In that study, three specific research questions were addressed,

1. What are the barriers encountered prior to entry?

2. What are the barriers encountered in the headship?

3. How can the participation of women in school leadership be enhanced?

In this report we first review prior understandings about the barriers associated with under-representation of female administrators in education, and describe the study. Then we present the participants' perspectives on the factors that militate against Kenyan women moving into school principalships. This is followed by a comparison of what they said against what the literature indicated, so as to highlight similarities and differences in the experiences of Kenyan female principals and would-be principals, and women elsewhere in the world. Finally we present the participants' suggestions for improving women's access to the principalship.

\section{Review of Related Literature}

The literature that was most relevant to the study reported here pertained to female administrators' professional development, promotion, and under-representation. The essentials follow.

\section{Professional development defined}

In this paper we use the terms professional development, staff development, and in-service training to refer to all types of learning activities by professional 
educators, singly or in groups, that are aimed at developing their skills and knowledge, further career progress or promotion in the work place, and foster organizational growth (e.g., Day \& Alan, 1993; Craft, 2000). Furthermore, we accept the following points about professional development.

- First, professional development is usefully defined in terms of process, content, objectives, and stages.

- Second, as Dean (1991) noted, professional development can apply to both individual and organizational growth.

- Third, as noted by Bruce (cited in Dean, 1991), professional development can serve the additional function of creating contexts in which potential leaders may develop.

- Finally, since in-service training for teachers is linked to school effectiveness, responsibility for professional development must lie with and be shared by ministries of education, school boards, teacher organizations, and local schools (Bogonko, 1992; Carter, 1988; Day \& Alan, 1993; Savard, 1993).

\section{Professional development in Kenya}

\section{Programs}

In post-independence Kenya, teachers' professional development has been provided through the In-service of Teachers programmes. According to Ayot (1982, p. 11), in-service of teachers refers to "refresher, orientation, and induction courses, [as well as] crash programmes for teachers." However, these programmes for teachers have been "sporadic and not meant to raise the professional status of the teachers” (Bogonko, 1992, p. 189; emphasis added). And this claim is supported by the findings of a study of primary school teachers in Kenya (Ackers, Migoli, \& Nzomo, 2001) who found that half the teachers interviewed had not received any in-service training.

\section{Promotion policies}

Promotion of primary school teachers to administrative positions is the responsibility of the Teachers Service Commission (TSC). According to a circular from the Teachers Service Commission (1998),

A teacher is eligible for an interview for entry to administrative position of a Deputy Head if she or he (1) possesses a P1 or S1 or ATS certificate, and (2) has served as assistant teacher for a minimum of five years.

It is important to note that the TSC does not stipulate teacher professional development as a requirement for promotion to a school administration position an anomaly that would seem to have contributed to poor administration in Kenya’s primary schools (Kitavi \& Westhuizen, 1997). 
Female under-representation in administration

Studies conducted in North America, England, Australia, and Greece suggest seven categories of factors related to the under-representation,

1. Stereotypes - The evidence suggests that male-like traits are preferred over female-like traits in the administration of schools; and this, in turn, leads to females who are not willing to accept masculine stereotypes declining positions that are defined in that manner (e.g. Coleman, 2000; Gill, 1995; Gupton \& Slick, 1996; Kruse, 2000; Sherman, 2000). Another stereotyping hindrance to the managerial careers of women is the widely accepted perception that "women are constructed as 'naturally' suited (as a consequence of their biology and childbearing capacities) to the primary roles of mothers and wives” (Kyriakoussis \& Saiti, 2006). And yet another impediment in this category, particularly in Greece, arises when men do not believe they have to share the responsibility of raising children and doing the housework (General Secretariat for Equality, 2000, p. 75).

2. Family, marriage, and mobility - The literature shows that married females shoulder more of the family chores than their male partners do; and their disproportionate share of housework increases the difficulty of pursuing careers in school leadership, particularly so when relocation is required ( Coleman, 2000; Gill, 1995; Grace, 1995; Kruse, 2000; Kyriakoussis \& Saiti, 2006; Sherman, 2000).

3. Role models - Another explanation for the lack of women in school administration is a lack of female role models (Kruse, 2000; Shakeshaft, 1989). According to Shakeshaft, for example, they are unable to hear "how [practicing female leaders] describe their lives, and compare themselves with women just one step farther up the hierarchy” (p. 115)

4. Mentors and networking - Closely linked to the influence of role models is the fact that females lack the mentors and networks that are important factors in promotion to leadership positions in schools (Kyriakoussis \& Saiti, 2006; Shakeshaft, 1989; Young, 1994). A related factor is that females tend to receive less information about job opportunities and programs for preparing leaders (Edson, 1988; Shakeshaft, 1989; Sherman, 2000; Young, 1994).

5. Isolation and marginalization -Females who attain school leadership positions tend to suffer social isolation and marginalization as they pursue their careers (Coleman, 2000; Gill, 1995; Sherman, 2000; Young, 1994).

6. Hiring practices - The research evidence suggests that discriminatory hiring practices based on gender have excluded females from positions in school administration. In addition, it seems that discriminatory recruitment practices may have deterred potential applicants (Gill, 1995; Kruse, 2000; Gupton \& Slick, 1996; Limerick \& Anderson, 1999; Shakeshaft, 1989; ). In Greece, Kyriakoussis \& Saiti (2006) found that 37\% of the female teachers they surveyed believed that 
"promotions into school administration are discriminatory." In similar vein, the Greek Teachers' Organization (2002, p. 62) noted that promotion in the Greek education system is subjective and contaminated by political motives.

7. Training and experience opportunities - The literature shows that at times women lack adequate training, experience, and educational opportunities to prepare them for leadership positions (Shakeshaft, 1989; Gupton \& Slick, 1996). In Greece, $43 \%$ of the females in Kyriakoussis \& Saiti's (2006) survey accused the education system of failing to encourage and motivate women to seek promotions early in their careers.

In conclusion, in Kenya the under-representation of women in educational administration positions is a fact (Mwangi-Chemnjor, 1995). However, the factors that militate against females moving into school administration in the schools of Kenya have not been investigated qualitatively and may not be the same as those in North America, England, Australia, and Greece. Hence, we cannot be sure how the situation in Kenya might be ameliorated.

\section{A Study of Aspiring and Incumbent Female School Administrators in Kenya}

In this study we explored the lived experiences of females who held or aspired to school headships in Kenyan public primary schools. The study was carried out in one rural district of Kenya. We used qualitative techniques because they (a) focus on peoples' lives in terms of their idiosyncratic experiences, perspectives, thoughts, behaviours, and activities (Clandinin \& Connelly, 2000; Bogdan \& Biklen, 1998) and (b) "examine how people learn and make sense of themselves and others” (Berg, 1998; p.7). Using this approach, we encouraged participants to discuss freely their experiences and stories about being Heads of public primary schools in Kenya.

To be eligible to participate, individuals had to meet the following criteria,

- The first and primary criterion was that participants were working in headship positions (either Head/Deputy) or as Assistant Teachers (those who have been interviewed for headship position but have not been assigned to one).

- In addition we tried to ensure that participants (a) had a range of experience for neophytes to veterans, (b) had been "invited" to an interview for a headship position, (c) represented a variety of age groups,

(d) had a variety of qualifications, and (e) were married or single.

Eight women participated in the study. In this report we have assigned pseudonyms to preserve anonymity.

Data were collected through loosely structured interviews. The interview questions focused on the journey to the headship, being in a headship, under- 
representation of females, and strategies to increase the number of women in school leadership positions.

Two types of interviews were conducted, eight individual and one focusgroup. For the individual interviews, participants were visited in their respective schools and interviewed using the following guide and a tape-recorder,

- Please tell me about your path to the headship (where appropriate),

(a) How many years have you taught since obtaining professional teaching certificate?

(b) Please tell me about how you came to the decision to pursue a career in headship.

- Please tell me about the barriers or roadblocks that you experienced in your pursuit of the headship position.

- Please tell me about the barriers or constraints that you continue to experience in this position.

- How have you attempted to overcome those barriers?

- How might we enhance women's participation in school leadership?

The focus-group discussion was also guided by the above statements/questions, and was audio-taped. All the recordings were later transcribed, and the transcripts were analyzed for patterns of regularity - that is, categories and themes (e.g., Clandinin \& Connelly, 2000).

\section{Findings}

In this district, females were a minority in school leadership. Although there were 311 Head Teacher and Deputy positions, females occupied only 15 of the headships (5\% and 36 of the 275 Deputyships (13\%).

Barriers to entering the headship

The female participants identified six barriers that militated against their entry to headship positions. These are, (1) family obligations, (2) cultural beliefs, (3) unethical recruitment practices, (4) lack of networking, (5) low expectation of success, (6) lack of role models and mentors.

\section{Family obligations}

The female participants talked of family commitments as a barrier that kept females from aspiring to headship positions or going for training away from their families. The participants felt that most women between 20 and 40 years of age would be "interested in the family" and only after age 40 would start "thinking of other things", including a career in the headship.

In addition the participants talked of the difficulties occasioned by having to take care of old parents and dependents. Some respondents felt that husbands were a 
hindrance to wives who aspired to headship positions. One woman, for example, said:

There are times when husbands refuse [to allow] the women to become Head. They will ask, "How can you become a Head when I am just an Assistant Teacher? (Yanoni)

A final disincentive of this type was that married women found it difficult to transfer from one school to another. One reason cited was women's concern about poor roads, security, and other infrastructure-related factors.

\section{Cultural beliefs}

The participants felt that, in general, society viewed females as persons who could not manage certain tasks and situations. This often results, for example, in male Head Teachers and Deputies undermining the authority of female teachers and humiliating them,

The Head Teacher, as well as your colleague the Deputy, can humiliate you in front of children. ... [For example] you might be disciplining a child and then the man [intervenes] and says, "You see...I want to help this teacher because you boys don't seem to obey her." (Hosina)

As a result, the participants said, most female teachers themselves believe that the headship is a career for men,

Since we were born, we have been thinking men are always the leaders. So, when the [administrator] jobs come up, we tend to wait for the men to apply first. (Hosina)

Drako, like other participants, also talked of facing a lot of criticism from her female colleagues when she applied for a Deputy position,

When I applied I met a lot of criticism at first. Some told me that this is a man's job, while others said that the community is so bad that you cannot manage .

\section{Discriminatory and unethical recruitment practices}

The participants felt that recruitment practices were biased against women and kept many from applying for leadership positions. They talked of encountering problems in all stages of the process of recruitment, including the advertisements, getting applications forwarded, the interviews, and the feedback processes. For example, one participant talked as follows about women being kept in the dark about vacant positions, learning only at the eleventh hour about interviewing sessions.

I did go for an interview for a headship this year [even though] the circular advertising the position came late.. There were one woman and four men on the [selection] panel. (Mibana) 
Other difficulties encountered while preparing applications included sexual harassment,

Some will want to take you for "lunch." And what kind of lunch? Especially for younger ones. ... They are "mishandled" and humiliated. (Mibana)

The participants said also that if a teacher reports to teach when she is pregnant, she will be told to go to lower primary - and will be confined to lower primary as long as she is having children.

Finally in this class of factors related to under-representation, some of the women became Head Teachers or Deputies of schools simply as a result of being in the right place at the right time - being appointed to a vacancy that arose within their school without having to go through a competition.

\section{Networking.}

The respondents talked of women not being appointed to leadership positions because they were not part of the extra-collegial network of relationships that support men. They said that in Kenya, where men can meet in their social places and discuss their affairs, it is unusual for women to meet in social places because they fear what people will think of them. In most Kenyan communities it is taboo for women to be seen in bars, clubs, or restaurant where alcohol is served; society views women who do this as being morally loose and shuns them.

\section{Low expectations of success}

Some participants felt there were fewer females in headships because they lack confidence and have a fear if failing in those positions. For example, one woman said that she had always wanted to be a Head Teacher but when she was appointed to the position she had a serious case of self-doubt, starting with the following thoughts.

I have an interest, but now the letter has come, how am I going to do this? How I am going to manage? (Pemura).

Most participants made reference to the fact that the work environment for Head Teachers is far from attractive. The logistical problems include lack of transport, unreliable postal services, lack of telephones, no access to email, inadequate lighting, and a dearth of school supplies.

\section{Lack of role models and mentors}

The participants noted that in some areas women have not observed a woman in a leadership position and, as a consequence, if a woman from that area were to be offered a headship, she might well turn it down. 
The participants talked also of male Head Teachers failing to encourage young female teachers to aspire to the headship, even discouraging young female teachers.

[The male Head Teacher] was shouting, "Get out of my office! And remove those plates [earrings] you are putting on your ears!” What has that have to do with him - how the teacher was dressing? So, even if the lady had an interest in applying for a headship, she wouldn't. (Mibana)

Barriers encountered once in the headship

The participants identified five barriers encountered on the job, stereotyped expectations and attitudes, getting compliance, the mother role, isolation, and marginalization

\section{Stereotyped expectations and attitudes}

In this regard one participant, for example, said that the majority of male teachers fully expect her to fail in her work because she is a woman,

When I was given my letter of appointment as Head Teacher, some men... [believed] I could not make it. [Later,] after they had experience with me, they said that a women could make it. However, at first they had a negative attitude. (Pemura)

Hostility from both male and female teachers was a major concern of women in the headship.

They did not get warm receptions from teacher colleagues, especially the females.

[They'd say,] "What can a woman tell me, a fellow woman? What can she really tell me?” And then they tended to ignore or insult me. And such a situation, if you don't know how to handle it, can get very rough. (Pemura)

The participants who were Deputies also felt that they were being monitored and watched closely by everybody, including the Head Teacher, other teachers, the community, and even the District Office - to see whether or not they would make it. These participants had to prove continuously that they could manage, in large part because they were women.

\section{Getting compliance}

The participants talked of having difficulties in making teachers do certain tasks. For example, one participant recalled that in her early days as a Deputy, teachers thought that "I was not the right person to assign them to work." Rosina recounted two incidents of non-compliance by teachers. The first happened when her Head Teacher left her in charge of the school,

I told some male teachers to go to class. "Even if we don't go," one of them even said, "You are a woman. You cannot tell me to go and teach." 
In the second incident, some male teachers wouldn't seek permission from her. Instead “They just marched away. They wouldn't ask a woman.” Mother role

The participants reported that teachers, children, and parents more often consulted them as mothers rather than administrators. Those who were Deputies in maleheaded schools found that everybody turned to them rather than the male Head.

We are happy that you, as a mother, were appointed. We can tell you the problems that we are not free to tell the Head Teacher because he is very strict with us and our children. (Hosina)

The participants found that as long as they played the mother role, the school community accepted them.

\section{Isolation}

Some participants felt isolated from fellow female teachers after being appointed to the headship. For example, one respondent found that,

You lose the fellowship of your colleagues. ... I don't know whether it is in their attitudes. Once you become their Head, the majority tend to fear you. (Mibana)

\section{Marginalisation}

Some of the Deputies talked of not being delegated their rightful duties and being under-utilized. At times their Head Teachers denied them designated responsibilities, substituting male teachers.

I [was responsible for] doing the administration and the other Deputy was in charge of curriculum. But I found he had given permission to teachers without my knowledge. When I asked why, he said I should not ask. (Mibana)

The participants talked of being marginalized also in Head's meetings where men were the majority. Their contributions were not taken seriously and, in the more extreme cases, they were not even allowed to participate in the meetings.

\section{Discussion}

We turn now to the implications of the findings of this study for understandings about the under-representation of women in the administration of schools. Table I on page 15, compares the impediments to moving into administrative positions in education that were reported by the Kenyan women against the impediments identified in the literature reviewed. 
Table I

Barriers in Kenya Data vs. Barriers in Literature Reviewed

\begin{tabular}{|c|c|}
\hline Kenya & Literature \\
\hline $\begin{array}{l}\text { Family obligations } \\
\text { - keep females too busy; husbands don't share } \\
\text { household work } \\
\text { - } \text { keep females from aspiring to headship } \\
\text { positions } \\
\text { - husbands openly discouraging } \\
\text { - going for training away from families } \\
\text { - } \text { militate against demonstrating talents in public } \\
\text { - } \text { arenas } \\
\text { difficult to transfer from one school to another }\end{array}$ & $\begin{array}{l}\checkmark \\
x \\
x \\
\checkmark \\
x \\
\checkmark\end{array}$ \\
\hline $\begin{array}{l}\text { Cultural beliefs \& attitudes, stereotypes } \\
\text { - females' should be mothers \& wives } \\
\text { - } \text { society views females as not able to manage } \\
\text { certain tasks and situations - administrators } \\
\text { undermine authority, female teachers believe } \\
\text { headship a career for men, criticism from } \\
\text { female colleagues } \\
\text { - females lack confidence, fear failing in } \\
\text { administration } \\
\text { - male teachers expect females to fail } \\
\text { - colleagues (especially females) hostile } \\
\text { influencing subordinates - difficult to get } \\
\text { compliance } \\
\text { consulted more as mothers than as } \\
\text { administrators - by teachers, children, and } \\
\text { parents }\end{array}$ & $\begin{array}{l}\checkmark \\
\checkmark \\
\text { - females unwilling to accept } \\
\text { masculine stereotypes decline } \\
\text { positions defined in that } \\
\text { manner } \\
\checkmark \\
\mathrm{x} \\
\mathrm{x} \\
\mathrm{x}\end{array}$ \\
\hline $\begin{array}{l}\text { Discriminatory and unethical recruitment, } \\
\text { placement, \& supervisory practices } \\
\text { - } \text { recruitment practices biased - advertisements, } \\
\text { getting applications forwarded, interviews, } \\
\text { feedback processes, sexual harassment, } \\
\text { exaggerated minimum qualifications } \\
\text { - promotion through being in the right place at } \\
\text { the right time - no competition, nepotism } \\
\text { - close monitoring - have to prove continuously }\end{array}$ & $\begin{array}{l}\checkmark \\
\text { - male-like traits preferred } \\
\text { over female-like traits } \\
\checkmark \\
\text { - contaminated by politics } \\
\text { x }\end{array}$ \\
\hline
\end{tabular}




\begin{tabular}{|l|c|}
\hline they can manage & x \\
\hline $\begin{array}{l}\text { Lack of networks } \\
\text { - excluded from extra-collegial network of } \\
\text { relationships that support men (taboo for } \\
\quad \text { women to be seen in bars, clubs, or restaurant) }\end{array}$ & $\checkmark$ \\
\hline $\begin{array}{l}\text { Lack of role models and mentors } \\
\text { - } \quad \text { no opportunity to observe a woman in a } \\
\text { leadership position } \\
\text { male Head Teachers fail to encourage young } \\
\text { teachers }\end{array}$ & $\checkmark$ \\
\hline $\begin{array}{l}\text { Indequate training } \\
\text { - lack of preparation programs }\end{array}$ & $\checkmark$ \\
\hline $\begin{array}{l}\text { Unattractive work environment } \\
\text { - Head Teachership onerous - logistical problems }\end{array}$ & $\checkmark$ \\
\hline $\begin{array}{l}\text { Isolation } \\
\text { - lose fellowship of colleagues }\end{array}$ & $\checkmark$ \\
\hline Marginalisation & \\
\hline
\end{tabular}

$\mathrm{x}=$ data-literature discontinuity

$\checkmark=$ data-literature parallels

“- females unwilling ...” = extra detail found in data

In what follows we will comment first on a general feature in the discontinuities in the table (which are marked with xs). Then we will comment on the parallels (marked with $\checkmark$ s). Finally, we will relate the findings to themes that have emerged recently in the literature on leadership, specifically the attention given to values and to the management of relationships.

\section{Discontinuities}

Many of the discontinuities in Table I (marked with xs) do not point to new factors identified by the Kenyan women but to variants of barriers recognised in 
the literature reviewed earlier. For example, in that literature there were no references specifically to,

- women kept from "demonstrating their talents in public arenas", or

- cultural attitudes that had female heads/principals being "consulted more as mothers than as administrators by teachers, children, and parents”, or

- women being barred from promotion by virtue of pregnancy, or

- female principals having duties withheld, being under-utilized.

But these are clearly specific instances of family responsibilities, cultural attitudes and beliefs, discriminatory hiring practices, and marginalization - not new barriers.

Parallels

There are many parallels in Table I - much of the Kenyan picture mirrors what has been portrayed for other countries. In their finer details, though, these findings add some important nuances and suggest directions for further research.

\section{Beliefs and attitudes}

As Table I indicates, the experiences of the Kenyan female administrators with disadvantageous beliefs and attitudes parallel those of their counterparts in other countries.

First, traditional gender stereotypes continue to contribute to female underrepresentation in other countries (e.g., Canada - Sherman, 2000; Greece Kyriakoussis \& Saiti, 2006; USA \& Greece - Lyman, Athanasoula-Repa, \& Lazaridou, in process).

Second, our finding that the Kenyan women had a fear of failing in administrative positions and lacked confidence has been noted by other researchers. For example, in a Canadian study Porat (1985, p. 12) found that,

[Women] labor under negative self-perception, lack of confidence in their qualifications and experience, and low expectations of success.

Third, the inadequacies in infrastructure that contributed significantly to the Kenyan participants' apprehensions may be significant in other jurisdictions the literature seems to be silent on this. It would be interesting to know whether or to what extent they contribute to the under-representation of female school administrators, particularly in remote and impoverished areas. This may be a question for further research.

Fourth, the non-compliance described by the Kenyan teachers, which was grounded in the belief that women are not suited to lead, has been mentioned also in North American studies (e.g., Gabler, 1987; Edson, 1988). Related to this, it seems, are finding that women who are appointed to administrative positions lose the friendship of other teachers, especially other females, and are marginalized (Coleman, 2000; Sherman, 2000; Young, 1994). It is important to note that the 
impediments in this category are grounded in strongly held values - which might be explored more fully with qualitative studies.

\section{Discriminatory recruitment practices}

In this area, the Kenyan aspirants' experiences parallel those of their North American and Greek counterparts. For example, in one Canadian study, Gill $(1995,56)$ also found that those who "succeeded in leadership were those who had contracts with those who hire." Similarly, in Greece the legislation regarding selection of educational managers (Presidential Decree 25, 2002) does not establish consistent selection criteria, and promotion in the Greek education system is subjective and obscured by political motives (Greek Teachers Organisation, 2002, p. 62).

As to being appointed to a school administration position by happening to be in the right place at the right time, this occurs not just in Kenya. What we call "fortuitous promotions" have been reported numerous times. For example, Young (1994, 359) noted that some women became educational administrators through "unexpected job openings."

In contrast, though, factors such as sexual harassment and inability to have applications processed are no longer as common in North America as they are in Kenya. The reason is that Kenya lacks legislation (and related enforcement) that militates against unfair treatment and discrimination on the basis of such criteria as sex and/or gender.

Contrary to the view that training and qualification facilitates entry into leadership, we found that possession of higher qualifications did not guarantee female headship positions in Kenya. As in other countries, such factors as personal connections, community influence, and religion played a significant role.

We suggest that discriminatory promotion practices may not be primary causes of under-representation of women in educational administration. It may be more useful to see them as proxy indicators, the outcome or operationalization of another cause - politics. And if one takes this perspective, an important focus in attempts to eliminate the under-representation of women would have to be the management of values and ideologies.

\section{Networking, role models, and mentors}

The participants, it will be recalled, talked of women not being appointed to leadership positions because they were not part of the extra-collegial network of relationships that support men, and because they did not meet in social places to discuss career affairs. This situation does not exist in North America, where society has generally accepted that women have equal rights. It would be very unusual for women to be interrogated about their social whereabouts, or to have gathering places reserved for men only. Interestingly, though, a study in Canada 
by Sherman (2000, p. 19) revealed that men networked "unconsciously, informally, and privately." It is also interesting to note the claim that Greek educational administrators failed to encourage and motivate women in seeking promotions early on in their careers (Kyriakoussis \& Saiti, 2006) which runs counter to a finding that is common in Canada, the USA, and Greece, where female administrators frequently acknowledge significance of their networks (e.g., Lyman, Athanasoula-Reppa, \& Lazaridou, in progress). This ambiguity, too, suggests further inquiry is necessary.

The Kenyan participants indicated that they frequently had no experience of female administrators, were discouraged openly and vigorously by male administrators, and were relegated by male administrators to low-status teaching as long as they were building their families. These particular Kenyan findings do not have parallels in North America data. Nonetheless, numerous investigators have found that many women would not have attempted the principalship were it not for principals who informed them of their abilities.

\section{Family}

Family concerns are an issue for not just female school administrators in Kenya; the Kenyan teachers' experiences are similar to those of women elsewhere in the world. But we want to emphasize an additional aspect of the "family" finding. It is important to recognize that competing values are at play too. This is evident in the finding that Kenyan female school administrators were consulted more as mothers than administrators. It is also clear in the case of Greek female teachers. The legislation for education in Greece does not include any restrictions on female representation in administrative and managerial positions, and the Greek State has social legislation that allows women to be employed without it adversely affecting either their occupation or their family situation (General Secretariat for Equality, 2000, pp. 53-56). Nonetheless, Kyriakoussis and Saiti (2006) reported that 37\% of their respondents expressed concern about the excessive demands of a managerial position, and they provided other indications that led these researchers to conclude that,

The unwillingness of female primary teachers to participate in school administration in recent decades may be attributed to the extra managerial responsibilities, work pressure, and hence the effects of managerial positions on their personal and social life. (Kyriakoussis \& Saiti, 2006; emphases added)

This tension between professional and family identities is being articulated more and more frequently and forcefully, it seems, in other parts of the world, in other occupational arenas, and by increasing numbers of men. For example, Grace (1995, p.184) found that female heads of primary schools referred to a continuous struggle between school and family, and were resentful of an 
erosion of personal time and space; Fris and Taylor $(2002)$ found that university Deans and Chairs were concerned about this issue too; and Erfani (2005) heard this refrain articulated forcefully, sometimes bitterly, by both the male and female university professors she interviewed.

Consequently, we suggest that person-role conflicts should be given more attention in the dialogue abut the under-representation of women in school administration.

\section{Values in school leadership}

Recent trends in leadership theory and practise include an increased interest in what leadership is for - its ends. This focus on the ends of administration and leadership has been evidenced in numerous countries, including Australia, Canada, Denmark, England, Scotland, and the USA (Lyman, Athanasoula-Reppa, and Lazaridou, in progress). This trend has not involved a neglect of the hows of leadership - its instrumental structures and techniques - but a re-examination of the values pursued by means of those techniques. Thus the traditional organizational values of survival, control, growth, effectiveness, and efficiency (Hodgkinson, 1991) have been supplemented with such values as social justice, democratic community, ethical schools, and learning for all children (Furman, 2003). And this shift in thinking about leadership has also come to be seen as a lever for effecting changes in bureaucratic systems that exist to serve the status quo (Lyman et al. in progress).

In this connection it is interesting to compare the values implicit in the Kenyan female school principals' narratives with those identified by others. For example, the Canadian school principals in Lazaridou's (2002) study most often referenced the following values,

- Collaboration - achieving common goals through teamwork and coordinated efforts; requires humility, sharing of authority and power, valuing dialogue and critical thinking.

- Consideration and care - taking others into account and ensuring that they know they are considered significant; having concern for the physical, emotional, and social welfare of others.

- Mission - valuing a strong and clear sense of direction and purpose, being true to the public's expectations; having and enforcing clear rules and expectations, and maintaining good communications and relations with the public.

These values were evident in the Kenya data, but the women often noted that they could not act sufficiently on them. One explanation may be the same as Lyman et al. (2006) found in their comparative study of American and Greek female school principals. Specifically, they found that values such as these often appeared to be stifled by the bureaucratic system, being clearly expressed in the 
principals' behaviours only when they had deliberately chosen to engage in creative insubordination in order to remain true to their values.

\section{Managing relationships}

We would like to point out also that many of the problems associated with underrepresentation of women in educational administration ultimately have to do with relationships among people. For example,

- The "family" class of factors were problems in that they jeopardized the women's bonds with their children and husbands.

- Concerns about "discriminatory recruitment practices" and the "values" categories were partly grounded in moral issues of equality, fairness, equal respect, and so on.

- Networking, mentoring, and role modeling are all about relationships.

And when the factors that seem to militate against women accessing administrative positions are viewed this way, it becomes clear that the emerging management literature on the applicability of complexity theory is relevant. This literature emphasizes the importance of building relationships,

In management theory the atomism of the [systems perspective] leads to an emphasis on delimiting roles and controlling boundaries (Stacey, Griffin, \& Shaw, 2000, p. 65). ... The holism of the [complexity] perspective leads to an emphasis on free-flowing interaction and codetermination ... building an ethos of cooperation and integration that is very different from the [bureaucratic] ethos of control (Fris \& Lazaridou, 2006).

\section{Getting more Women into School Leadership}

Strategies

The Kenyan women in this study identified four general areas where improvements could be made to increase the rate at which women participate in school leadership, educating the public, preparation through training and exemplars, and recruitment.

\section{Preparation, Seminars and workshops}

The participants offered a wide range of suggestions for preparing women for administrative positions.

The participants felt that there is a need for seminars that address the various issues faced by females who aspire to leadership positions. These would include seminars that focus on traditional beliefs, gender issues, and balancing family and work. 
The participants pointed to misguided beliefs held by community should be addressed in seminars. Such communities should be informed that teachers are allowed by contract to take 60 working days of paid maternity leave; that the teacher is expected to shoulder some of an absent teacher's work load; and that teachers can be re-deployed to where they are needed because school teachers are trained in all subjects that are taught in primary schools.

The participants suggested also that communities should be educated to accept women as leaders, perhaps by pointing out that since women are involved in community leadership they should be able to lead in the education field too.

The participant also felt that the issue of family commitments has not been given adequate attention. They said that women have long been shouldering the brunt of such family commitments as taking care of children, husband, and in-laws.

To mitigate the problems associated with family commitments, the participants suggested, female teachers should be trained in how to balance work and family. This issue, and possible solution, was identified by Shakeshaft (1989) too, who noted that in the United States women have made inroads into leadership because many programs for women and bureaus for women have been made available. These measures include special administrative training programs for women, as well as internships that provide useful lessons in assertiveness, stereotyping, and balancing of women's lives.

The participants felt, however, that most women are not ready to attend seminars that are residential. They suggested that those responsible should be aware of this and, accordingly, plan on-site seminars and workshops. The participants felt also that seminars should be organized to address gender equity issues. Yet other participants suggested that a course for spouses be included in gender awareness programs, so that husbands can learn to be more responsive to their wives' needs.

\section{Exemplars, Role models, mentors, and networking}

The participants felt that female teachers lack role models and mentors to nurture them to leadership.

The participants felt that females in leaderships should prepare female teachers for leadership roles. They said that those in leadership should inspire other women.

The participants felt that there is a need to network themselves. One participant suggested that they could "form alliances, and meet during the day and in the halls, but not where men meet." Some participants suggested that women could be employed to inform others of imminent promotion opportunities. Some participants suggested that women in headships be encouraged to engage in networking to help aspirants, as well as newly appointed female leaders, become successful administrators. 
In general, then, it became clear that the participants felt that seminars, role models, and mentors would be effective in preparing females for school leadership positions. This is supported in Young's (1990) synthesis of recommendations from Canadian writers for advancing women in leadership positions. The strategies described therein included awareness workshops for prospective women administrators, establishment of formal mentoring programs, incentives for women taking leadership training, and thorough induction programs for newly recruited women administrators. In similar vein, Kruse (2000) reported that networking and mentorship are some of the options that enables women to overcome barriers and become administrators.

\section{Recruitment, Streamlining the process}

The participants felt that existing recruitment practices do not provide females with a level playing field when competing with males for leadership positions. They suggested that panels should be gender-balanced and that vacant position $\mathrm{s}$ should be made public. And they also said that they should band together to complain to relevant authorities about recruitment abuses.

These findings correspond to the findings of studies by Sherman (2000), Young (1990), and Shakeshaft (1989). For example, Shakeshaft $(1989,206)$ found strong evidence that there was a need to examine the "interview and selection procedures for the presence of bias so that the best person is hired.”

\section{Recommendations}

In view of the above findings, we recommend the following,

1. The Ministry of Education, Science, and Technology and the Teachers Service Commission should vigorously strengthen anti-discrimination policies pertaining to the appointment of Teachers and Deputies, and school leadership preparation programs. For example, dropping the requirement that a woman who is promoted must get a consent letter from her husband before being transferred to a different station.

2. The District Education Boards - who develop and manage education at the district level, and whose members are drawn from all stakeholders in the local community - should initiate programs to sensitize their communities to genderrelated issues and the importance of supporting women who in leadership.

3. The Kenya Union of Teachers (KNUT) should initiate similar sensitizing programs for its members. The majority of teachers in Kenyan schools are members of KNUT and therefore is in an influential position to promote gender equity.

4. The Primary Teacher Training College's curriculum should be expanded to include gender studies. This will help erase some stereotypes about women and leadership. 
5. Women and men who are already in school leadership positions should commit more strongly than before to mentoring potential female Heads.

6. Qualitative research should be conducted to investigate the questions raised by this study,

a) What roles do infrastructure factors play in the under-representation of female school administrators in urban and rural settings?

b) What values are at play in the under-representation of female school administrators?

c) What roles do value conflicts, particularly person-role conflicts, play in the under-representation of female school administrators?

d) Do effective school administrators rely heavily on building and sustaining an ethos of cooperation and integration?

\section{References:}

Ackers, J., Migoli, J., \& Nzomo, J. (2001) Identifying and addressing the causes of declining participation rates in Kenyan primary schools, International Journal of Educational Development, 21, pp. 361-374.

Ayot, H. (1982) In-service training of primary school teachers in Kenya (Bristol, GB, Bristol University School of Education).

Berg, L.B. (1998) Qualitative research methods for the social sciences (Boston, MA, Allyn \& Bacon).

Bogdan, R.C., \& Biklen, S.K. (1998) Qualitative research in education, An introduction to theory and methods (Boston, MA, Allyn \& Bacon).

Bogonko, S.N. (1992) A history of modern education in Kenya (1895-1991) (Nairobi. Kenya, Evans Brothers (Kenya) Ltd).

Canadian Teacher's Federation. (1999-2000) Take another look at our school,. ESN, Dec/Jan., pp. 22-25.

Carter, L. (1988) $A$ vision of professional development, Professional development in the county of Minburn \#27. Unpublished master's project, University of Alberta, Edmonton, Alberta, Canada.

Clandinin, D.J., \& Connelly, F.M. (2000) Narrative inquiry, Experience and story in qualitative research (San Francisco, CA, Jossey-Bass Publishers).

Coleman, M. (2000) The female secondary Head Teacher in England and Wales, Leadership and management styles, Education Research, 42(1), pp. 13-27.

Craft, A. (2000) Continuing professional development, A practical guide for teachers and schools (London, GB, Routledge Falmer).

Day, C., \& Alan, P. (1993) Conceptualising professional development planning, A multidimensional model, Journal of Education for Teaching, 2(19), pp. 251-260. 
Dean, J. (1991) Professional development in school (Milton Keynes, Philadelphia, Open University Press).

Erfani, N.G. (2005) Through the "I" of the education professor. Unpublished doctoral dissertation, University of Alberta, Alberta, Canada.

Fris, J., \& Lazaridou, A. (2006) An additional way of thinking about organizational life and leadership, Canadian Journal of Educational Leadership and Policy, Issue 48.

Fris, J., \& Taylor, G. (2002) The work of academic deans and chairs. Paper presented at the Annual Meeting of the Canadian Society for Studies in Education, Toronto.

Edson, S.K. (1998) Pushing the limits, The female administrative aspirants (Albany, NY, State University of New York).

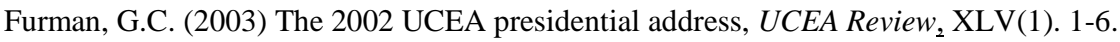

Gabler, J.E. (1987) Leadership, A woman's view in, T.L. Shieve \& M.B. Shoeheit (Eds) Leadership, Examining the elusive (pp. 64-77) Association for Supervision and Curriculum Development.

General Secretariat for Equality. (2000) National report of Greece (4th \& 5th) for the period 1994-2000 to the UN Commission for the elimination of all forms of discrimination against women (Athens, Greece, Ministry of the Interior, Public Administration, \& Decentralisation).

Gill, B. (1995) Breaking the ceiling or sliding back the sunroof? Women in educational administration in New Brunswick in, C. Reynolds \& B. Young (Eds) Women and leadership in Canadian education (Calgary, AB, Detselig Enterprises).

Grace, G. (1995) School leadership, Beyond educational management, An essay in policy scholarship (U.K., Falmer Press).

Greek Teachers’ Organisation. (2002) Didaskaliko Vima, July-August. (in Greek)

Gupton, L.S., \& Slick, A.G. (1996) Highly successful women administrators, The inside stories of how they got there (Thousand Oaks, CA, Corwin Press).

Hodgkinson, C. (1991) Educational leadership, The moral art (Albany, NY, State University of New York Press).

Kitavi, M.W., \& Westhuizen, P.C. Van Der. (1997) Problems facing beginning principals in developing countries: A study of beginning principals in Kenya. International Journal of Educational Development, 17(3), pp. 251-263.

Kruse, J. (2000) The times they aren't a-changing: Thirty years of women in administration. Unpublished master's project, University of Alberta, Edmonton, Alberta, Canada.

Kyriakoussis, A., \& Saiti, A. (2006) Under-representation of women in public primary school administration: The experience in Greece. International Electronic Journal for Learning in Leadership, 10.

Lazaridou, A. (2002) An exploratory study of leaders' thinking and problem solving through protocol analysis Doctoral dissertation, University of Alberta, Edmonton, Alberta, Canada.

Limerick, B., \& Anderson, C. (1999) Female administrators and school-based management: New models in an era of change? Educational Management and Administration, 27(4), pp. 410-413.

Lyman, L.L., Ashby, D. E., \& Tripses, J.S. (2005) Leaders who dare: Pushing the boundaries (Lanham, MD, Rowman \& Littlefield Education).

Lyman, L.L., Athanasoula-Repa, A., \& Lazaridou, A. (in progress) Greek and US women leaders as democratic change agents: A cross-cultural analysis.

Ministry of Education, Greece (1999) Direction of Studies in Primary Education (in Greek) (Author, Athens). 
Mwangi-Chemnjor, C. (1995) Women in post secondary education administration in Kenya. Unpublished master’s thesis, Dalhousie University, Halifax, Nova Scotia, Canada

Porat, K. (1985) The woman in the principle’s chair The ATA Magazine, May-June, pp. 1015.

Presidential Decree \#25. (2002) (Athens, Greece, Hellenic Republic).

Savard, J.D. (1993) Professional development of teachers, A case study. Unpublished master's thesis, University of Alberta, Edmonton, Alberta, Canada.

Shakeshaft, C. (1989) Women in educational administration (Newbury Park, CA, Corwin Press).

Sherman, A. (2000) Women managing/managing women: The marginalisation of females in rural school settings. Educational Management and Administration, 28(2), pp. 133-143.

Smith, L. (1991) The gender composition of the pool of prospective school principals. Canadian Journal of Education, 16(2), pp. 198-205.

Stacey, R.D., Griffin, D., and Shaw, P. (2000) Complexity and management, Fad or radical challenge to systems thinking? (London, GB, Routledge).

Teachers Service Commission. (1998, February 26) Reminder, Appointment and confirmation of primary heads and deputies Circular Letter TSC/ADM/192A, VOL. VI (Nairobi, Kenya, Author).

Young, B. (1990) Not yet there, Women in educational administration in: Y.L. Lam (Ed) The Canadian public school system, Issues and prospects (pp. 85-102) (Calgary, AB: Destselig Enterprises).

Young, B. (1994) Another perspective on the knowledge base in Canadian educational administration Canadian Journal of Education, 19(4), pp. 351-367.

Dr. Bosire Monari Mwebi is Assistant Professor, School of Education, St. Francis Xavier University, Antigonish, Canada, 203 Xavier Hall, P. O. Box 5000,

Antigonish, Nova Scotia, Canada. B2G 2W5

Email: bmwebi@stfx.ca

Dr.Angeliki Lazaridou is Assistant Professor at the Intercollege, Cyprus. Her research interests include school effectiveness, leadership, school leadership, organizational behavior, values in Education, cognition and leadership, women in administration, complexity theory in organizational studies and stress in administration. 